\title{
PARTIAL CHARACTERIZATION OF PROTEASES FROM STREPTOMYCES CLAVULIGERUS USING AN INEXPENSIVE MEDIUM
}

\author{
Keila Aparecida Moreira ${ }^{1,5}$; Maria Taciana Holanda Cavalcanti ${ }^{1,5}$; Helena Simões Duarte ${ }^{2}$; \\ Elias Basile Tambourgi ${ }^{3}$; Eduardo Henrique Magalhães de Melo ${ }^{1}$;Valdinete Lins Silva ${ }^{4}$; \\ Ana Lúcia Figueiredo Porto ${ }^{2,5}$; José Luiz de Lima Filho ${ }^{1,5 *}$
}

${ }^{1}$ Departamento de Bioquímica, Universidade Federal de Pernambuco, Recife, PE Brasil; ${ }^{2}$ Departamento de Morfologia e Fisiologia Animal, Universidade Federal Rural de Pernambuco, Recife, PE, Brasil; ${ }^{3}$ Departamento de Separação Química, Faculdade de Engenharia Química, Universidade Estadual de Campinas, Campinas, SP, Brasil; ${ }^{4}$ Departamento de Engenharia

Química and ${ }^{5}$ Laboratório de Imunopatologia Keizo Asami, Universidade Federal de Pernambuco, Recife, PE, Brasil

Submitted: August 28, 2000; Returned to authors for corrections: January 17, 2001; July 23, 2001

\begin{abstract}
The partial characterization of extracellular proteases from Streptomyces clavuligerus NRRL 3585 and 644 mutant was investigated. The enzyme production was carried out in batch fermentation using soy bean filtrate as nitrogen source. Maximum activity was obtained after $96 \mathrm{~h}$ of fermentation with an initial $\mathrm{pH}$ of 7.0. The enzyme was partially purified by ammonium sulphate precipitation. Enzymes from the two strains retained $37 \%$ of their initial activities at $\mathrm{pH} 8.0$ after $2 \mathrm{~h}$ incubation at $25^{\circ} \mathrm{C}$. Enzyme half-life at $\mathrm{pH} 8.0$ and $60^{\circ} \mathrm{C}$ was 40.30 and $53.32 \mathrm{~min}$, respectively for both strains (partially purified extract). The optimum $\mathrm{pH}$ was obtained at $\mathrm{pH}$ 7.0-8.0 and 8.4 for enzymes produced for 3585 and 644 strains (crude extract), respectively, and 8.4 and 8.0 for enzymes from the partially purified extract 3585 and 644 strains, respectively. The optimum temperature for the crude extract was $21^{\circ} \mathrm{C}$ for both strains. However, for the partially preparation the optimum temperature was $50^{\circ} \mathrm{C}$ and $40^{\circ} \mathrm{C}$ for $S$. clavuligerus NRRL 3585 and 644 strains respectively.
\end{abstract}

Key words: Streptomyces clavuligerus, extracellular proteases, thermal stability, pH

\section{INTRODUCTION}

Proteases are the most important class of industrial enzymes and comprise about $25 \%$ of commercial enzymes on the world. Two thirds of the industrially produced proteases are from microbial source $(5,10)$. The major applications of these enzymes are in the food, pharmaceutical and detergent industries. Alkaline proteases are mostly used in enzyme-containing detergent powders, and have minor uses in food processing, e.g. childproofing of beer and production of protein hydrolysate (13). Acid protease plays an important role in meat tenderization and in the production of fermented foods by moulds from soybean, rice and others cereals (12). They are also used in the baking industry for the modification of wheat proteins in the bread industry and in the dairy industry for clotting of milk to manufacture cheese (2). Porto et al. (15) have studied Streptomyces clavuligerus cultures for protease production and reported that the amount of enzyme produced varies greatly with the culture media used. Proteases from Streptomyces origin offer an advantage as the mycelium can be easily removed by filtration (13). In order to assess the utility of the Streptomyces clavuligerus proteases for industrial detergents use, properties such as $\mathrm{pH}$ and temperature stability of the crude and partial purification extract were determined.

\section{MATERIALS AND METHODS}

\section{Microorganisms}

Streptomyces clavuligerus NRRL 3585 and mutant 644, isolated in medium with high concentration $(600 \mathrm{mg} / \mathrm{mL})$ of clavulanic acid (4), were used in this study. The microorganisms were maintained at $28^{\circ} \mathrm{C}$ on ISP-2 agar slants (16), made up of malt extract $(1.0 \% \mathrm{w} / \mathrm{v})$, yeast extract $(0.4 \% \mathrm{w} / \mathrm{v})$, agar-agar $(2.0 \% \mathrm{w} / \mathrm{v})$.

\footnotetext{
* Corresponding author. Mailing address: Universidade Federal de Pernambuco, Laboratório de Imunopatologia Keizo Asami (LIKA), Setor de Biotecnologia, Av. Moraes Rego, S/N. 50670-420, Recife, PE, Brasil. E-mail: zeluiz@hotlink.com.br
} 


\section{Production media and culture conditions}

The inoculum was carried out using Erlenmeyers flasks (250 $\mathrm{mL}$ ) containing $50 \mathrm{~mL}$ of the fermentation medium described by Porto et al. (15), which contained the following components: glycerol $(1.0 \% \mathrm{w} / \mathrm{v})$, soy bean filtrate $(0.5 \% \mathrm{w} / \mathrm{v}), \mathrm{MgSO}_{4} .7 \mathrm{H}_{2} \mathrm{O}$ $(0.06 \% \mathrm{w} / \mathrm{v}), \mathrm{NH}_{4} \mathrm{Cl}(0.1 \% \mathrm{w} / \mathrm{v}), \mathrm{K}_{2} \mathrm{HPO}_{4}(0.435 \% \mathrm{w} / \mathrm{v})$ and 0.1 $\mathrm{mL}$ mineral solution $\left(100 \mathrm{mg}\right.$ of the $\mathrm{FeSO}_{4} \cdot 7 \mathrm{H}_{2} \mathrm{O}, \mathrm{MnCl}_{2} \cdot 4 \mathrm{H}_{2} \mathrm{O}$, $\mathrm{ZnSO}_{4} \cdot \mathrm{H}_{2} \mathrm{O}, \mathrm{CaCl}_{2} \cdot \mathrm{H}_{2} \mathrm{O}$ distilled water $100 \mathrm{~mL}$, with initial 7.0). Culture was grown for $48 \mathrm{~h}$ at $28^{\circ} \mathrm{C}$, in an orbital shaker $(200$ rpm). Growth curve experiments were carried out using Erlenmeyers flasks $(500 \mathrm{~mL})$ containing $125 \mathrm{~mL}$ of the culture medium started with $10 \%(\mathrm{v} / \mathrm{v})$ inoculum, orbital shaking (200 $\mathrm{rpm})$ over $96 \mathrm{~h}$ at $28^{\circ} \mathrm{C}$. Samples were removed at time intervals $(24 \mathrm{~h})$ and supernatants were used to measure protease activity and protein concentration.

\section{Biomass determination}

The biomass concentration was determined as mycelia dry weight after centrifugation ( $5000 \mathrm{~g}$ for $5 \mathrm{~min}$ ) of $10 \mathrm{~mL}$ of culture broth in duplicate, and dried at $105^{\circ} \mathrm{C}$ overnight until constant weight.

\section{Protease assay}

Total extracellular protease was assayed at $25^{\circ} \mathrm{C}$ as described by Ginther (6) in culture medium previously clarified by centrifugation (12000 g for $5 \mathrm{~min}$ ). Azocasein, $1.0 \%$ (w/v) (Sigma, ST. Louis, Mo USA) in 0.2 M Tris-HCl, pH 7.2, containing 1.0 $\mathrm{mM} \mathrm{CaCl}{ }_{2}$, was used as substrate. One unit of activity was defined as the amount of enzyme that produces an increase in the optical density of $1.0 \mathrm{in} 1 \mathrm{~h}$ at $440 \mathrm{~nm}$. Protein was determined using the method described by Bradford (3), with bovine serum albumin as the standard.

\section{Effect of $\mathrm{pH}$ on protease activity}

For determination of optimum $\mathrm{pH}$ of the enzyme, the reaction mixture buffer of the azocasein $1 \% \mathrm{w} / \mathrm{v}$ was varied over the $\mathrm{pH}$ range 5.0 - 9.0. The buffers used were citrate-phosphate $(\mathrm{pH} 5.0$ - 5.7, 0.1M), phosphate ( $\mathrm{pH} 6.0-8.0,0.1 \mathrm{M})$, and Tris- $\mathrm{HCl}(\mathrm{pH} 7.2$ - 9.0, 0.2M) Pimentel et al. (14).

\section{Effect of temperature on protease activity}

For the determination of optimum temperature, the reaction mixture containing of azocasein $1 \%(\mathrm{w} / \mathrm{v})$ was incubated over a range of temperature from of $21^{\circ} \mathrm{C}$ to $70^{\circ} \mathrm{C}$ using $0.2 \mathrm{M}$ Tris$\mathrm{HClpH}$ 8.0.

\section{Thermal stability of protease}

For the determination of the thermal stability, the enzyme was pre-incubated over range of temperature from $21^{\circ} \mathrm{C}$ to $70^{\circ} \mathrm{C}$. The time of incubation of the samples varied from 30 to 120 minutes. After incubation, the samples were submitted to determination of protease activity, using the azocasein $1 \%(\mathrm{w} / \mathrm{v})$ at $25^{\circ} \mathrm{C}(11)$.

\section{Stability at different $\mathrm{pH}$ values}

The enzyme was incubated at $25^{\circ} \mathrm{C}$ in buffers of different $\mathrm{pH}$ values ( $\mathrm{pH} 6.5-8.0,0.1 \mathrm{M}$ buffers as above). The time of incubation samples varied from 30 to 120 minutes. Protease activity of the samples was measured at $25^{\circ} \mathrm{C}$, using $0.2 \mathrm{M}$ Tris$\mathrm{HCl}$ buffer, $\mathrm{pH} 8.0$ for samples 3585 and $644 \mathrm{pH} 8.5$.

\section{Partial purification with ammonium sulphate}

To remove mycelia, the 96 hours culture broth was centrifuged and ammonium sulphate was added to the supernatant to give a concentration of $20 \%$ saturation. The precipitate was removed by filtration. The ammonium sulphate concentration was increased stepwise to $100 \%$ saturation, where at every additional $20 \%$ of ammonium sulphate, precipitates were collected by filtration. The collected precipitates were dissolved in deionised water and dialysed against phosphate buffer $0.1 \mathrm{M} \mathrm{pH}$ 7.0. After exclusion of ammonium sulphate, proteolytic activity in each dialysed solution was assayed by the method described Ginther (6).

\section{RESULTS AND DISCUSSION}

Protease production throughout this study was determined after 96 hours of growth, which corrresponded to the optimum period for enzyme production (Fig. 1 and 2). Both figures show that the activity keeps going up, but the biomass decreases after 50 hours of growth. These results are in agreement with Bascaran et al. (1), who showed that synthesis of protease by Streptomyces clavuligerus starts in the post-exponential phase of growth. As we can see from Fig. 1 and 2, proteases activities was could be detected 10 hours of growth and increased after the exponential phase.

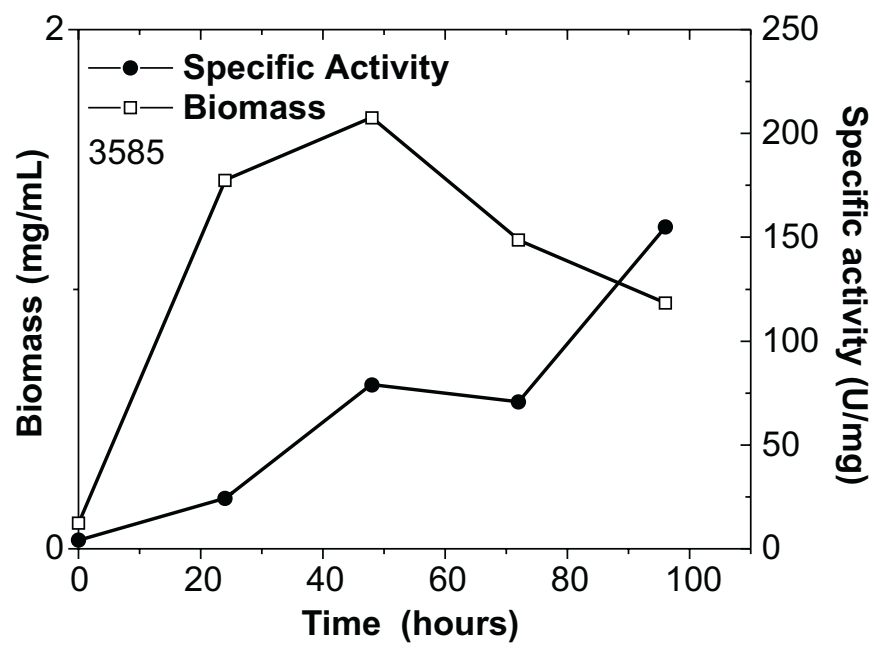

Figure 1. Biomass $(\square)$ and specific activity $(\mathbf{O})$ of protease from $S$. clavuligerus 3585 . 


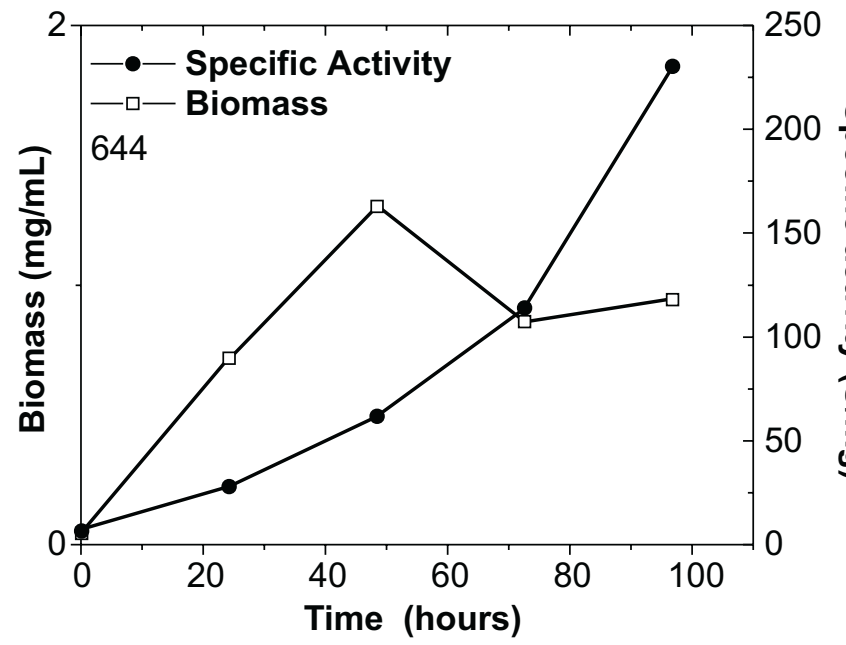

Figure 2. Biomass $(\square)$ and specific activity ( $\bigcirc)$ curves of proteases from $S$. clavuligerus 644 .

Experiments reported by Bascaran et al. (1), using $S$. clavuligerus for protease production after nutritional shift-down, indicated that initiation of protease formation is observed with decreased nutrients available. Good enzyme production was obtained using nitrogen-free medium or in presence of poorly utilized amino acids, but decreased with amino acids supporting higher growth rate.

The mechanisms by which control of protease production is achieved in many prokaryotes systems are not still known (1).

\section{The effect of $\mathrm{pH}$ on activity and stability of protease}

The effect of $\mathrm{pH}$ on protease activity is shown in Figs. 3 and 4 . The optimum activity for both proteases was at $\mathrm{pH} 7.0$ 8.0 and 8.4, respectively for enzymes produced by 3585 and 644 strains (crude extract). These results are in agreement with those found by Sampath et al. (17) for another strain of Streptomyces (Streptomyces spp.). There the optimum $\mathrm{pH}$ was around 7.0-8.4 for almost several substrates used, and it was stable over $\mathrm{pH}$ range 6.5-8.0 and very unstable after $\mathrm{pH}$ 10.0 .

However these results are compatible with t obtained with the Conidiobolus coronatus protease (13), which showed a high level of stability up to $\mathrm{pH} 8.0$, which is the $\mathrm{pH}$ of most commercial detergent solutions. At present, there is considerable interest in the identification of alkaline proteases that act effectively as detergent enzymes when used at ambient temperature. This is essentially due to the energy cost involved in heating the water for washing. In countries like Brazil, detergents are commonly used at room temperatures $\left(28^{\circ} \mathrm{C}\right)$ and hence, the enzyme could be promising for this application, in spite of being less stable to heat than the Bacillus enzymes. Fig. 5 and 6 also show the stability of proteases in various $\mathrm{pH}$ values. The enzymes were stable over a $\mathrm{pH}$ range 6.5 - 8.0 and

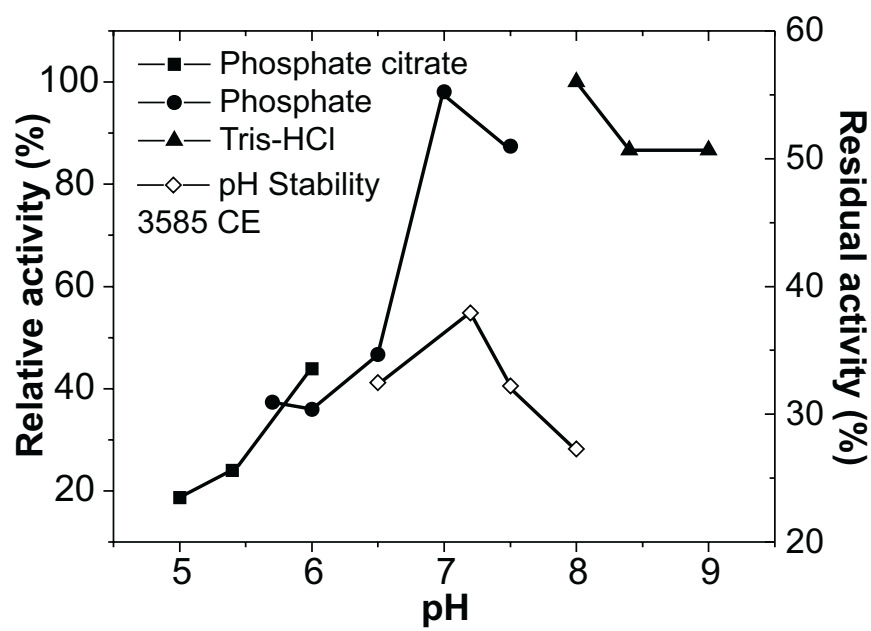

Figure 3. Effect of pH on activity $(\boldsymbol{\square}, \mathbf{O}$ and $\mathbf{\Delta})$ and stability of protease $(\diamond)$ from S.clavuligerus 3585 (crude extract -CE).

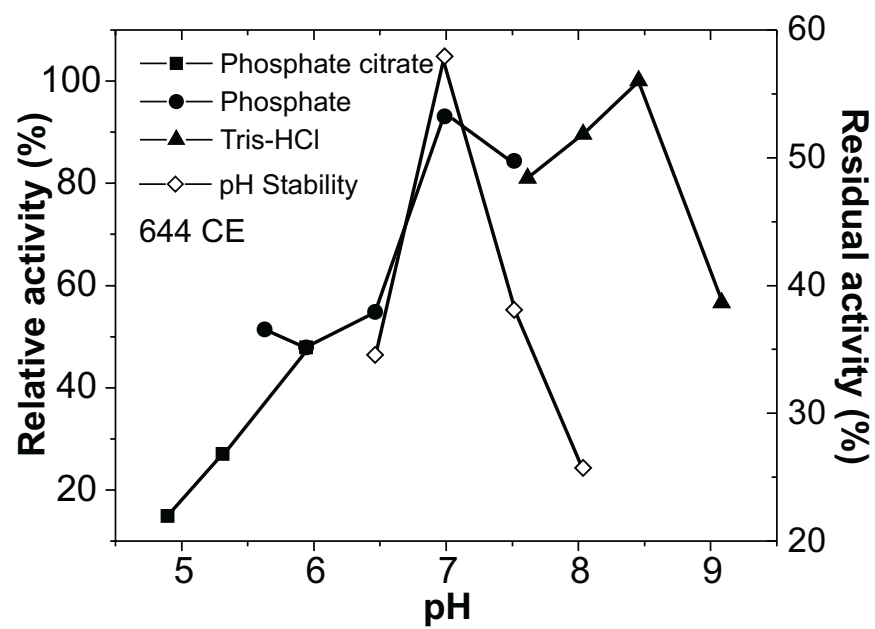

Figure 4. Effect of $\mathrm{pH}$ on activity $(\boldsymbol{\square}, \mathbf{O}$ and $\mathbf{\Lambda})$ and stability of protease $(\diamond)$ from $S$. clavuligerus 644 (crude extract-CE).

6.5 - 7.5 for proteases produced from 3585 and 644 strains (PPE), respectively. Approximately $37 \%$ (3585 and 644) activity remained after $120 \mathrm{~min}$.

The partially purified extract of protease from $S$. clavuligerus 644 PPE in $\mathrm{pH} 7.5$ retained less than $62 \%$ of this activity in the presence of $\mathrm{Cl}^{-}$ions, where $\mathrm{HCl} 0.2 \mathrm{M} \mathrm{pH} 8.0$ buffer solution was used.

\section{Effect of temperature on activity and stability of protease}

Thermostability of enzyme was investigated at $21^{\circ}-70^{\circ} \mathrm{C}$ at $\mathrm{pH}$ 8.0. The enzyme was stable at $21^{\circ} \mathrm{C}$ for 120 minutes $(100 \%)$, therefore the enzyme was stable a wide range $30^{\circ}-60^{\circ} \mathrm{C}$, its retained about 28 and $40 \%$ activity during this time for crude extract 3585 and 644 , respectively. 


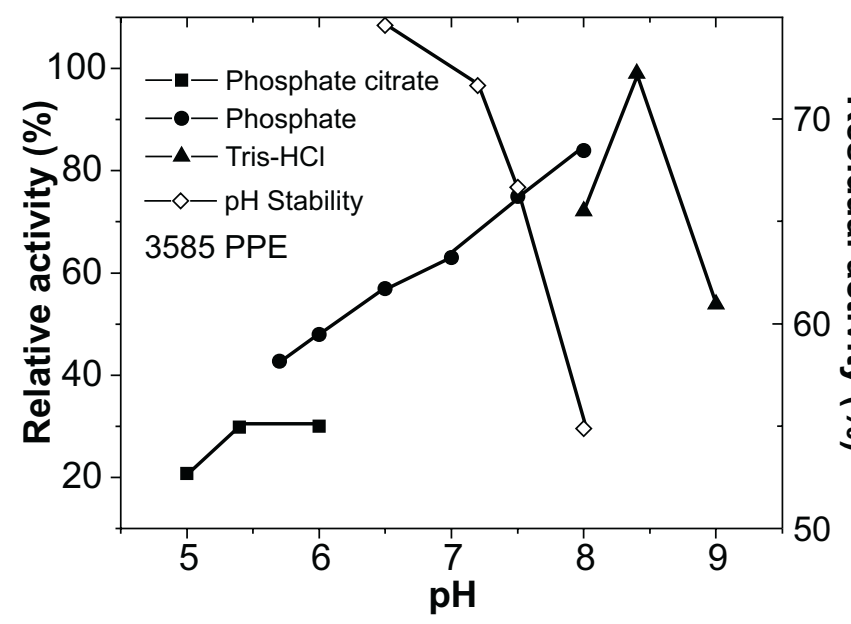

Figure 5. Effect of $\mathrm{pH}$ on activity $(\boldsymbol{\square}, \boldsymbol{O}$ and $\boldsymbol{\Delta})$ and stability of protease $(\diamond)$ from $S$. clavuligerus 3585 (partially purified extract - PPE - fraction $80-100 \%$ ).

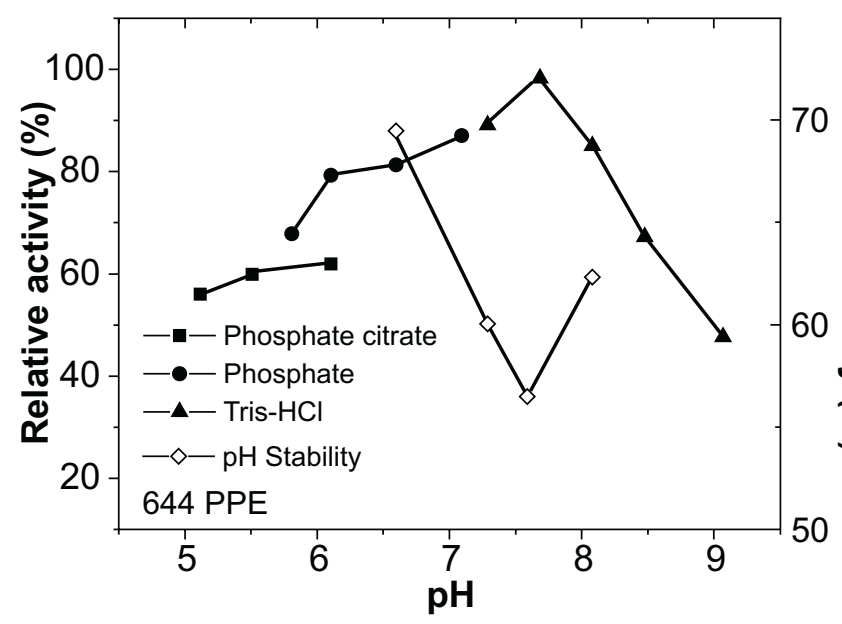

Figure 6. Effect of $\mathrm{pH}$ on activity $(\boldsymbol{\square}, \mathbf{O}$ and $\mathbf{\Delta})$ and stability of protease $(\diamond)$ from $S$. clavuligerus 644 (partially purified extract - PPE - fraction $80-100 \%$ ).

After 2 hours at $70^{\circ} \mathrm{C}$, the activity was completely lost for both enzymes (crude extract and partially purified) because of thermal inactivation (Fig. 7 and 8). In the Fig. 7, the decay constant at $\mathrm{pH} 8.0$ at different temperatures of incubation is shown. Proteases from Aspergillus oryzae and Aspergillus cladie lost their activities beyond $40^{\circ} \mathrm{C}(7)$.

The protease from Endothia parasitica was found to be inactive within $5 \mathrm{~min}$ at $60^{\circ} \mathrm{C}(8)$. The present protease from $S$. clavuligerus exhibited greater thermal stability than the enzymes from other fungal sources, suggesting possible biotechnological and industrial impotance.

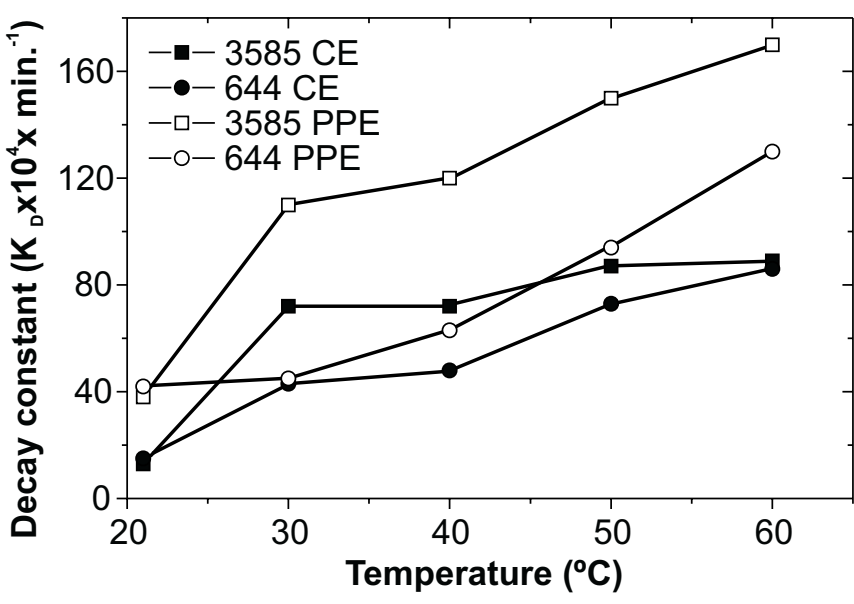

Figure 7. Decay constant for $\mathrm{pH} 8.0$ at different temperatures of proteases from $S$. clavuligerus 3585 (ם) and 644 (O) using crude extract - $\mathrm{CE}$ and $3585(\square)$ and $644(\mathrm{O})$ partially purified PPE (fraction $80-100 \%$ ).

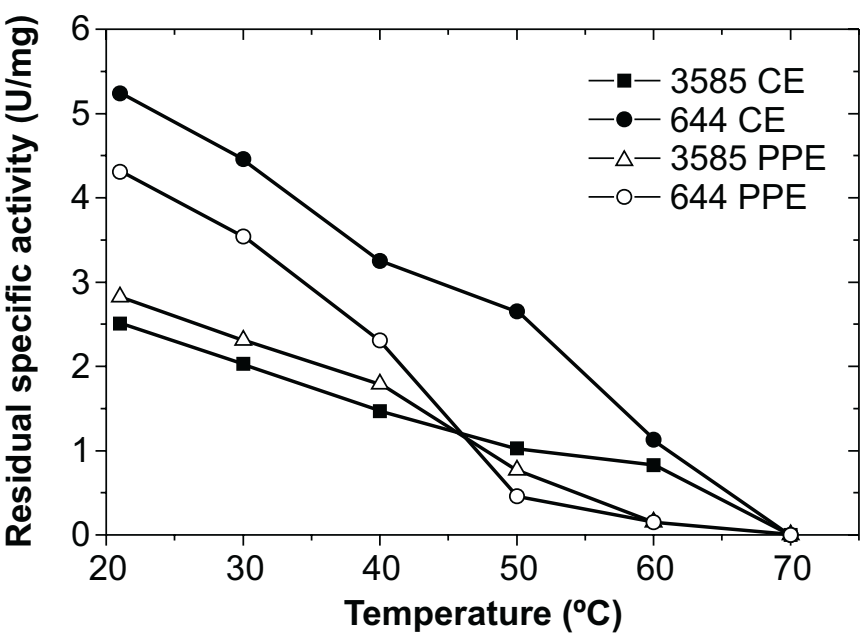

Figure 8. Thermal stability of proteases from $S$. clavuligerus $3585(\square)$ and $644(\bigcirc)$ and using crude extract- $C E$ and $3585(\triangle)$ and $644(O)$ partially purified - PPE (fraction $80-100 \%$ ).

As shown in Fig. 9 and 10, the enzymes have an optimal activity at $21^{\circ} \mathrm{C}$ for crude extract, and $50^{\circ} \mathrm{C}$ and $40^{\circ} \mathrm{C}$, respectively, for strains 3585 and 644 partially purified extract. This behaviour could be explained by the presence of an inhibitor, which is activated at temperatures above $20^{\circ} \mathrm{C}$.

However, the purification procedures seem to eliminate the inhibitor from the medium. Comparing the curves for optimum temperature for activity and for thermal stability, it can be seen that they are not coincident. The curves obtained by Kang et al. (9). 


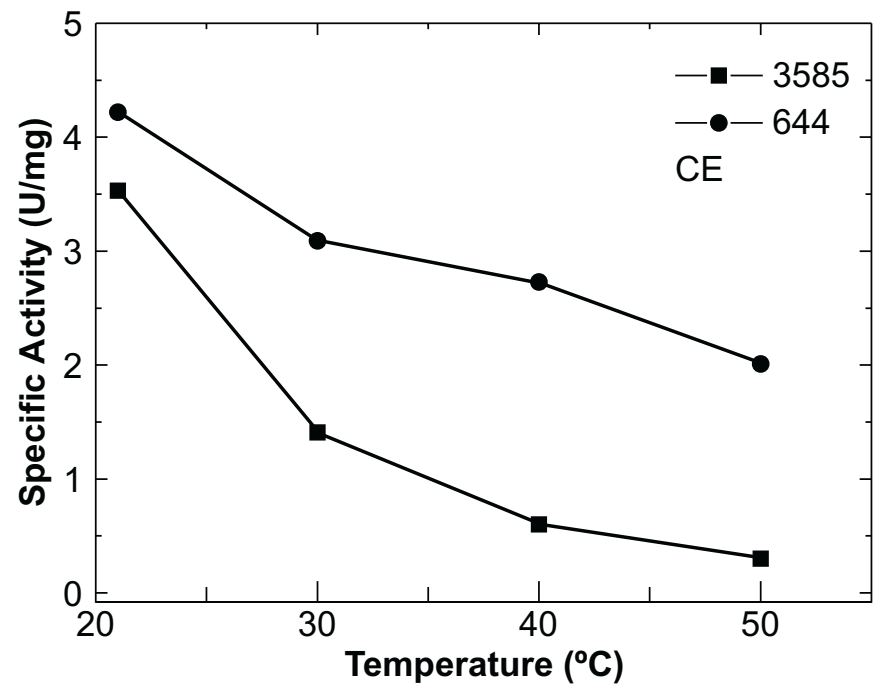

Figure 9. Temperature optimum of proteases from $S$. clavuligerus 3585 (口) and 644 (O) using crude extract-CE.

The phase for extracellular protease from Streptomyces albidoflavus, showed an optimum temperature at $40^{\circ} \mathrm{C}$, and unstability at temperatures above $45^{\circ} \mathrm{C}$ during 90 minutes. Optimum temperature for thermostable proteases by Aspergillus niger and Aspergillus saitoi have been found to be $60^{\circ}$ and $30^{\circ} \mathrm{C}$, respectively $(8,18)$.

\section{ACKNOWLEDGEMENTS}

This work was supported by CNPq (Brazil), CAPES, FACEPE, Federal University of Pernambuco, and Rural Federal University of Pernambuco.

\section{RESUMO}

\section{Caracterização parcial de proteases extracelulares de Streptomyces clavuligerus usando um meio de cultura econômico}

A caracterização parcial de proteases extracelulares de Streptomyces clavuligerus foi investigada. A produção da enzima foi realizada pela fermentação em batelada utilizando farinha de soja como fonte de nitrogênio. O máximo rendimento foi obtido após 96 horas de fermentação com um $\mathrm{pH}$ inicial de 7,0. A enzima foi purificada parcialmente por precipitação com sulfato de amônia. Ambas enzimas reteram $37 \%$ de sua atividade inicial a pH 8,0, após 2 horas de incubação a $25^{\circ} \mathrm{C}$. O tempo de meia-vida das enzimas foi de 40,30 e 53,32 minutos, respectivamente para ambos 3585 e 644 (extrato parcialmente purificado) a $\mathrm{pH} 8,0$ e $60^{\circ} \mathrm{C}$. Com relação ao $\mathrm{pH}$, a atividade ótima foi alcançada a $\mathrm{pH} 7,0-8,0$ e 8,4 para enzimas produzidas

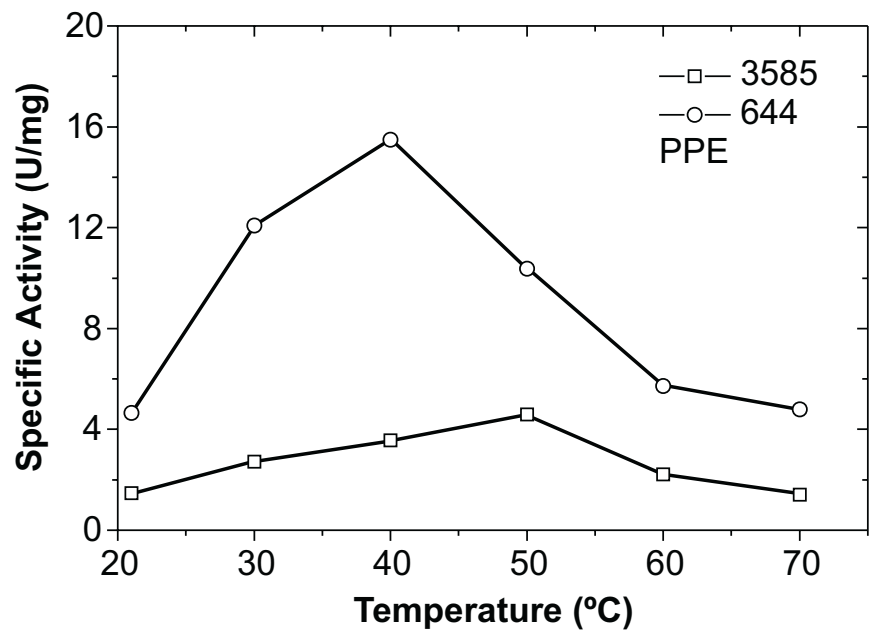

Figure 10. Temperature optimum of proteases from $S$. clavuligerus $3585(\square)$ and $644(\bigcirc)$ using extract partially purified - PPE - fraction $80-100 \%$.

pelas amostras 3585 e 644 (extrato bruto) respectivamente e 8,4 e 8,0 para as enzimas obtidas a partir dos extratos parcialmente purificados das amostras 3585 e 644, respectivamente. A temperatura ótima para o extrato bruto foi de $21^{\circ} \mathrm{C}$ para $S$. clavuligerus NRRL 3585 e 644 . Contudo, para a preparação parcialmente purificada, a temperatura ótima foi de 50 e $40^{\circ} \mathrm{C}$ para amostras $S$. clavuligerus NRRL 3585 e 644 respectivamente.

Palavras-chave: Streptomyces clavuligerus, proteases extracelulares, estabilidade térmica, $\mathrm{pH}$

\section{REFERENCES}

1. Bascaran, V.; Hardisson, C.; Braña, A.F. Regulation of extracellular protease production in Streptomyces clavuligerus. Appl. Microbiol. Biotechnol., 34:208-213, 1990.

2. Boing, J.T.P. Enzyme production. In: Reed, G. (ed). Prescott and Dunn's Industrial Microbiology. Connecticut: AVI, 1982, p.690.

3. Bradford, M.M. Rapid and sensitive method for quantitation of microgram quantities of protein utilizing principle of protein-dye binding. Anal. Biochem., 72:248-254, 1976.

4. Donaduzzi, C. Selection de mutants superproducteurs d'acide clalanique et resistanys aux beta-lactamines chez Streptomyces clavuligerus. Lorraine, 1990, 144p. (PhD. Theses Ecole Nationale Superieure d'Agronimic et des Industries Alimentaries, Institut National Potytechnique).

5. Gerhartz, W. Enzymes in Industry: Production and Applications. VCH, Weinnheim, 1990, 88p.

6. Ginther, C.L. Sporulation on the production of serine protease and cephamycin C by Streptomyces lactamduran. Antimicrob. Agents Chemother., 15:522-526, 1979.

7. Jaya R.; Ayyanna, C. A comparison of immobilized protease from plant and microbial souces. In: Ayyanna, C. (ed). Recent Trends In Biotechnology. Tata Mcgraw-Hill, New Delhi, 1993, p.25-30.

8. Kalisz, H.M. Microbial proteinases. Adv. Biochem. Engin. Biotech., 36:1-65, 1988. 
9. Kang, S.G.; Kim, I.S.; Rho, Y.T.; Lee, K.J. Production dynamics of extracellular proteases accompanying morphological differetiation of Streptomyces albidoflavus SMF301. Microbiology, 141:30953103, 1995.

10. Moon, S.H.; Parulekar, S.J. A parametric study of protease production in batch an fed batch cultures of Bacillus firmus. Biotechnol. Bioeng., 37:467-483, 1991 .

11. Morimura, S.; Kida, K.; Sonoda, Y. Production of protease using waste water from the manufacture of shochu. J. Ferment. Bioeng., 77:183-187, 1994

12. Nout, M.J.R.; Rombouts, F.M. Recent developments in tempe research. J. Appl. Bacteriol., 69:609-633, 1990.

13. Phadatare, S.U.; Deshpande, V.V.; Srinivasan, M.C. High activity alkaline protease from Conidiobolus coronatus (NCL 86.8.20): Enzyme production and compatibility with commercial detergents. Enzyme Microb. Technol., 15:72-76, 1993.
14. Pimentel, M.C.B.; Krieger, N.; Coelho, L.C.C.B.; Fontana, J.O.; Melo, E.H.M.; Ledingham, W.M.; Lima Filho, J.L. Lipase from a brazilian strain of Penicillium citrinum. Appl. Biochem. Biotech., 49:59-74, 1994.

15. Porto, A.L.F.; Campos-Takaki, G.M.; Lima Filho, J.L. Effects of culture conditions on protease production by Streptomyces clavuligerus growing on soy bean flour medium. Appl. Biochem. Biotech., 60:115-122, 1996.

16. Pridham, T.G.; Anderson, P.; Foley, C.; Lindenfelser, L.A.; Hesseltine, C.W.; Bendict, R.G. A selection of media for maintenance and taxonomic study of Streptomycetes. Antibio. Annu., 947-953, 1957.

17. Sampath, P.; Subramanian, C.; Chandrakasan, G. Extracellular proteases from Streptomyces spp. G157: purification and characterization. Biotechnol. Appl. Biochem., 26:85-90, 1997.

18. Singh, A.; Ghosh, V.K.; Ghosh, P. Production of thermostable acid protease by Aspergillus niger. Lett. Appl. Microbiol., 18:177-180, 1994. 